DOI: https://doi.org/10.15407/techned2018.04 $: 041$

\title{
OPTIMAL COUPLING COEFFICIENT CALCULATION FOR INDUCTANCES IN INTERLEAVED BIDIRECTIONAL DC-DC CONVERTERS
}

Journal
Publisher
ISSN
Issue
Pages

\author{
Tekhnichna elektrodynamika
}

Institute of Electrodynamics National Academy of Science of Ukraine 1607-7970 (print), 2218-1903 (online)

No 4, 2018 (July/August)

$41-46$

\section{Authors}
K. Tytelmaier ${ }^{1 *}, 0$. Husev ${ }^{2 * *}$,
O. Veligorskyi ${ }^{2 * \star *}$
M. Khomenko ${ }^{2 \star \star * *}$
D. Maladyka ${ }^{2}$

1 - Tallinn University of Technology,

st. Ehitajate, 5, Tallinn, 19086, Estonia

2 - Chernihiv National University of Technology,

st. Shevchenko, 95, Chernihiv, 14035, Ukraine

e-mail: kostya.tytelmaier@gmail.com, oleksandr.husev@ieee.org,

oleksandr.veligorskyi@inel.stu.cn.ua

* ORCID ID : http://orcid.org/0000-0001-7582-0204

** ORCID ID : http://orcid.org/0000-0001-7810-457X

*** ORCID ID : http://orcid.org/0000-0002-8256-7339

**** ORCID ID : http://orcid.org/0000-0001-9084-3527

\section{Abstract}

This paper shows generalized calculation of coupling coefficient for two-phase interleaved bidirectional converter. Switching period of such system was divided on modes and main 
parameters of the system was analyzed in each mode. Current ripple in each phase can be easily determined using calculation results and it depends on the values of duty cycle and coupling coefficient. It is demonstrated that coupling coefficient affects on current ripple in phase, but not on output current ripple. Based on increasing of the one phase inductance due to coupling an optimal coupling coefficient can be selected. Experimental prototype of bidirectional interleaved two-phase converter proved theoretical hypothesis. References 15, figures 4.

Key words: bidirectional power flow, circuit analysis, dc-dc power converter, coupling inductors, pulse width modulation converter.

Received: 07.02.2018

Accepted: 13.03.2018

Published:

\section{References}

1. Tytelmaier K., Husev O., Veligorskyi O., Yershov R., A Review of Non-Isolated Bidirectional DC-DC Converters for Energy Storage Systems. Proc. of II International Young Scientists Forum on Applied Physics and Engineering

. Kharkiv, 10-14 October 2016. Pp. 1-7. DOI:

https://doi.org/10.1109/YSF.2016.7753752

2. Wong P.-L., Xu P., Yang B., Lee F.C. Performance Improvements of Interleaving VRMs with Coupling Inductors. IEEE Transactions on Power Electronics. 2001. Vol. 16. No. 4. Pp.

499-507. DOI:

https://doi.org/10.

$1109 / 63.931059$

3. Zu G., McDonald B.A., Wang K. Modeling and Analysis of Coupled Inductors in Power Converters. IEEE Transactions on Power Electronics. 2011. Vol. 26. No. 5. Pp. 1355-1363.

DOI:

https://doi.org/10.1109/TPEL.2010. 
2079953

4. Shin H.-B., Park J.G., Chung S.-K., Lee H.-W., Lipo T.A. Generalised steady-state analysis of multiphase interleaved boost converter with coupled inductors. IEE Proc.-Electric Power Application

. 2005. Vol. 152.

No. 3. Pp. 584-594. DOI:

https://doi.org/10.1049/ip-epa:20045052

5. Yang F., Ruan X., Yang Y., Ye Z. Interleaved Critical Current Mode Boost PFC Converter with Coupled Inductor. IEEE Transaction on Power Electronics. 2011. Vol. 26. No. 9. Pp.

2404-2413. DOI:

10.1109/TPEL.2011.2106165

6. B. Hesterman. Analysis and Modeling of Magnetic Coupling. Denver Chapter IEEE Power Electronics Society

. -2007. -

$93 \mathrm{p}$.

7. Qiu Y. Coupled inductors for power supplies. EE Times-India. 2007. Vol. 1. Pp. 1-4.

8. K. Kroics, U. Sirmelis, V. Brazis. Design of coupled inductor for interleaved boost converter.

Przeglad Elektrotechniczny

. 2014. Vol. 12. Pp. 91-94.

9. Ayele G.T. Challenges of Multi-channel Interleaved Bidirectional Power Converters and their Digital Solutions: author's abstract of Dr. tech. sci. diss. University of Nottinghan. Nottinghan. 2015. 73 p.

10. Ikriannikov A. The benefits of the coupled inductor technology. Maxim Integrated tutorial 5997. - 2014. - 10 p.

11. Yao K. High Frequency and High-Performance VRM Design for the Next Generation of Processors: author's abstract of Dr. tech. sci. diss. Virginia Polytechnic Institute and State University. Blacksburg. 2004. 193 p.

12. Wong P.-L., Performance Improvement of Multi-Channel Interleaved Voltage Regulator Modules with Integrated Coupling Inductors: author`s abstract of Dr. tech. sci. diss. Virginia Polytechnic Institute and State University. Blacksburg. 2001. 224 p.

13. Mu M., Lee F.C., Jiao Y., Lu S. Analysis and Design of Coupled Inductor for Interleaved Multiphase Three-Level DC-DC Converter. Applied Power Electronica Conference and Exposition (APEC). Charlotte. 15-19 March 2015. Pp. 2999-3006.

14. Texas Instruments. SLVA477B Basic calculation of a Buck Converters Power Stage. 2015. $-8 \mathrm{p}$.

15. Texas Instruments. AN-1197 Selecting Inductors for Buck Converter. - 2013. - 18 p.

\section{PDF}

